\title{
Determination of Selected Metals in Leaf and Root Bark of Malva Parviflora
}

\author{
Mesfin Medihin Ododo* Bezabih Kelta Wabalo \\ Department of Chemistry, Wolaita Sodo University, Wolaita Sodo, Ethiopia
}

\begin{abstract}
In Ethiopia, Malva parviflora (family: Malvaceae) leaf is used as a vegetable and its root bark is used to treat furuncles, carbuncles, wound infections and other related ailments. However, no research has been done to analyze essential and toxic metals in leaf part and the metals having antibacterial and wound healing activities in root bark of this plant. Thus, the present study was aimed to determine concentration of $\mathrm{K}, \mathrm{Na}, \mathrm{Mg}, \mathrm{Ca}, \mathrm{Fe}, \mathrm{Zn}, \mathrm{Cu}, \mathrm{Cd}, \mathrm{Pb}$, and $\mathrm{Ni}$ in leaf par; and $\mathrm{Mg}, \mathrm{Ca}, \mathrm{Fe}, \mathrm{Zn}, \mathrm{Cu}, \mathrm{Cd}, \mathrm{Pb}, \mathrm{Ni}$, and $\mathrm{Co}$ in root bark of Malva parviflora. The results revealed that the leaf part contains high amounts of $\mathrm{Na}, \mathrm{K}, \mathrm{Mg}$, and $\mathrm{Ca}$. Similarly, high concentrations of $\mathrm{Mg}$ and $\mathrm{Ca}$ were detected in the root bark. Appreciable amounts of $\mathrm{Fe}$ and $\mathrm{Zn}$, and low amount of $\mathrm{Cu}$ were detected in both leaf part and root bark. Concentrations of $\mathrm{Co}, \mathrm{Ni}, \mathrm{Cd}$, and $\mathrm{Pb}$ were below the method detection limit. Thus, leaf of Malva parviflora is a good source of essential nutrients ( $\mathrm{Na}, \mathrm{K}, \mathrm{Mg}, \mathrm{Ca}, \mathrm{Fe}$, and $\mathrm{Zn}$ ) and the presence of $\mathrm{Mg}, \mathrm{Ca}$, $\mathrm{Fe}, \mathrm{Zn}$ and $\mathrm{Cu}$ might contribute to the therapeutic action of root bark of Malva parviflora.
\end{abstract}

Keywords: Malva parviflora, Vegetable, Medicinal plants, Metals

DOI: $10.7176 / \mathrm{JNSR} / 9-6-01$

Publication date:March $31^{\text {st }} 2019$

\section{Background}

Malva parviflora (family: Malvaceae) is also commonly known as Uka (in Wolaita language) in Ethiopia. It is native to Asia, Northern Africa, and Europe and widely naturalized elsewhere. The plant often grows up to 40 inch in agricultural farmlands and waste places. Malva parviflora is an annual, biennial or perennial herb plant. It has a deep strong tap root system, dark green leaves, flowers that emerge from the base of the leaf stalks, and fruits that are sectioned into lobes (Ododo et al., 2016).

Food crops especially vegetables demands have been highly increased due to rapid growth of human population, and wild vegetables are used as alternatives crops to meet the food demands (Hussain et al., 2010). Malva parviflora leaf is cooked like spinach in Mexico (Sharma and Ali, 1999) and raw or cooked as a potherb in Ethiopia. A mild pleasant flavour, it makes a very acceptable alternative to lettuce in salads or cabbage. The beneficial health and nutrition values of leaf of Malva parviflora, for human consumption have been claimed by local users in rural area of Ethiopia. Raw or cooked immature seeds are also used as a vegetable.

Many medicinal plants are being used for both medicinal and nutritional purpose in different countries. They are considered as good source for providing essential elements, and thus the elements contribute therapeutic action of medicinal plants (Selvaraju et al., 2011). In the rural areas of Ethiopia, the root bark of Malva parviflora is used in herbal medicine very effective to heal furuncles, carbuncles and wound infections. The minor skin infections such as furuncles, carbuncles are usually caused by Staphylococcus aureus bacterium (Chakraborty et al., 2012), and Escherichia coli strains cause wound infections (Mos et al., 2010).

The scientific investigation of metals in the leaf part is important to know the nutritional values and their toxicity level. The metals contribution on therapeutic action of medicinal plants also should have been evaluated. Thus, study was aimed to determine concentration of selected metals in both leaf and root bark parts of Malva parviflora.

\section{Materials and Methods}

2.1 Description of the Study area

The study was carried out in around Shanto Town, Damot Pulassa Woreda, Wolaita Zone, Ethiopia. Damot Pulasa Woreda is one of the 12 districts in Wolaita Zone. Shanto is an administrative town of Damot Pulasa Woreda and located about $330 \mathrm{~km}$ from Addis Ababa, the capital city of Ethiopia to the southwest. It is found between latitude $07^{0} 01^{\prime} 28.2^{\prime \prime} \mathrm{N}$ and longitude $037^{0} 55^{\prime} 09.9^{\prime \prime} \mathrm{E}$ and lie at an altitudinal range of 1820-1880 $\mathrm{m}$ above sea level. The annual mean minimum and maximum temperatures are about 15.5 and $24.5^{\circ} \mathrm{C}$ respectively. The total mean annual rainfall is 1000 to $1270 \mathrm{~mm}$. The soil type of the study area is grouped under black basaltic soil.

\subsection{Apparatus and Glasswares}

A drying oven (Digital Heat, JP Selecta, Spain), mortar, pestle, precision balance (PGW 253i (ADAM), Switzerland), Kjeldahl digestion apparatus (BUCHI, Switzerland), and Whatman No. 42 filter paper with a 0.45$\mu \mathrm{m}$ were used. 


\subsection{Reagents and Instruments}

Nitric acid $\left(\mathrm{HNO}_{3}, 69-72 \%\right)$ (RANKEM, India), Analytical grade metal salts of $\mathrm{Na}, \mathrm{K}, \mathrm{Ca}, \mathrm{Mg}, \mathrm{Fe}, \mathrm{Co}, \mathrm{Ni}, \mathrm{Cu}$, $\mathrm{Zn}, \mathrm{Cd}$ and $\mathrm{Pb}$ and deionized water. Flame photometer (model CL 378, India) and flame atomic absorption spectrophotometer (model, PG-990 AAS, UK) were used to determine concentration of metals.

\subsection{Pretreatment of Glasswares}

To avoid contamination, all glasswares required for experiments were first washed with cold tap water using a detergent and then soaked in $20 \%$ (v/v) $\mathrm{HNO}_{3}$ for 48 hours, and finally rinsed with deionized water.

\subsection{Collection of the Samples}

Fresh plant materials were randomly collected from agricultural farmlands in the month of October, 2012 towards the end of the rainy season. Both leaf and root samples collected were kept separately in polyethylene plastic bags.

\subsection{Sample Pretreatment, Drying and Grinding}

The root materials were washed with tap water followed by deionized water to eliminate attached soil particles. The bark was the separated from the root and chopped into small pieces using a stainless steel knife. After drying in air, the sample was dried in an oven at $60{ }^{\circ} \mathrm{C}$ for $12 \mathrm{hr}$ to assure complete removal of moisture. It was then grinded using mortar and pestle, sieved $(2 \mathrm{~mm})$ to obtain uniform particle size. Both leaf and root bark powders were weighed and then stored in clean dried plastic bottles at room temperature for further analysis.

\subsection{Wet Digestion of Samples}

The wet sample digestion was carried out using Kjeldahl digestion apparatus with a reflux condenser for both leaf and root bark samples. Three parameters: temperature $\left(275^{\circ} \mathrm{C}\right)$, time $(3 \mathrm{hrs})$ and reagent volume $\left(15 \mathrm{~mL} \mathrm{HNO}_{3}\right)$ were optimized. Applying the optimized conditions, $1 \mathrm{~g}$ of each sample was digested for analysis. The digestion was carried out in triplicate for each sample. The digested solutions were allowed to cool at room temperature for $30 \mathrm{~min}$. To the cooled clear yellow solutions, $20 \mathrm{~mL}$ of deionized water was added, and solutions were then shaken to dissolve precipitates remaining on the wall of the digestion apparatus. Then, solutions were filtered into $100 \mathrm{~mL}$ volumetric flasks through a Whatman No. 42 filter paper with a $0.45-\mu \mathrm{m}$ to remove the impurities for metals analysis. The solutions were finally diluted to the mark with deionized water and kept in room temperature until analysis.

\subsection{Constructing Calibration curves}

To construct calibration curves, diluted standard solutions were prepared from their respective stock standard solutions $(1000 \mathrm{ppm})$ which were already-made by dissolving appropriate amounts of the their respective metal salts of analytical grade (purity 99.9\%) in $\mathrm{HNO}_{3}$ and diluting with deionized water. Preparation of the diluted standard solutions for each metal was depending upon the linear working range (Table 1). The absorbance of each solution was measured and calibration curves were constructed separately for selected metals to determine correlation coefficient $\left(\mathrm{r}^{2}\right)$.

Table 1: Standard solutions used for preparing calibration curves

\begin{tabular}{|c|c|c|c|c|c|c|c|c|c|c|c|}
\hline \multicolumn{12}{|c|}{ Concentration (ppm) of calibration standard solutions for each metal } \\
\hline Metal & $\mathbf{N a}$ & $\mathbf{K}$ & Mg & $\mathbf{C a}$ & $\mathbf{F e}$ & Co & $\mathbf{N i}$ & $\mathbf{C u}$ & $\mathbf{Z n}$ & Cd & $\mathbf{P b}$ \\
\hline \multirow{5}{*}{ 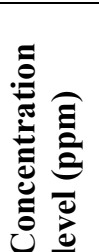 } & 0.50 & 0.50 & 0.50 & 0.50 & 0.50 & 0.50 & 0.50 & 0.25 & 0.25 & 0.25 & 0.50 \\
\hline & 10.00 & 10.00 & 1.00 & 1.00 & 1.00 & 1.00 & 1.00 & 0.50 & 0.50 & 0.50 & 1.00 \\
\hline & 15.00 & 15.00 & 2.00 & 2.00 & 2.00 & 2.00 & 2.00 & 1.00 & 1.00 & 1.00 & 2.00 \\
\hline & 20.00 & 20.00 & 3.00 & 3.00 & 3.00 & 3.00 & 3.00 & 1.50 & 1.50 & 1.50 & 4.00 \\
\hline & 25.00 & 25.00 & 4.00 & 4.00 & - & 4.00 & - & 2.00 & - & 2.00 & 8.00 \\
\hline
\end{tabular}

\subsection{Recovery Test}

The optimized procedure was validated by spiking each of triplicate leaf and root bark samples with the known concentration of standard metal solutions using a pipette (Table 2). The spiked samples were then digested using optimized procedure and analyzed to calculate percent recoveries.

Table 2: The spiked concentrations levels of selected metals

\begin{tabular}{|l|l|l|l|l|l|l|l|l|l|l|l|}
\hline Metal & Na & K & Mg & Ca & Fe & Co & Ni & Cu & Zn & Cd & Pb \\
\hline Concentration (ppm) spiked & 6 & 12 & 3 & 3 & 1 & 1 & 1 & 1 & 1 & 1 & 1 \\
\hline
\end{tabular}




\subsection{Method Detection Limit}

Method detection limits (3SD, where $\mathrm{SD}=$ Standard Deviation) for metals such as $\mathrm{Fe}, \mathrm{Co}, \mathrm{Ni}, \mathrm{Cu}, \mathrm{Zn}, \mathrm{Cd}$, and $\mathrm{Pb}$ were determined by digesting ten analytical reagent blank $(n=10)$.

\subsection{Analysis of the Selected Metals}

Concentrations of $\mathrm{Ca}, \mathrm{Mg}, \mathrm{Fe}, \mathrm{Cd}, \mathrm{Cu}, \mathrm{Pb}, \mathrm{Zn}, \mathrm{Ni}$, and $\mathrm{Co}$ were analyzed using flame atomic absorption spectrometry; whereas analysis of $\mathrm{Na}$ and $\mathrm{K}$ was performed in flame photometer. Triplicate determinations were carried out for each metal and the mean values were reported. The instrumental conditions during the analysis of each the metal is present in Table 3 .

Table 3: Standard conditions for Flame Atomic Absorption Spectrometry (FAAS) and flame photometry measurements

\begin{tabular}{|l|l|l|l|l|l|l|l|l|l|l|l|}
\hline Metal & Na & K & Mg & Ca & Fe & Co & Ni & Cu & Zn & Cd & Pb \\
\hline $\boldsymbol{\lambda}$ (nm) & 589.0 & 766.5 & 285.2 & 422.7 & 248.3 & 240.7 & 232.0 & 324.7 & 213.9 & 228.8 & 283.3 \\
\hline Slit(nm) & 0.2 & 4.0 & 0.4 & 0.4 & 0.2 & 0.2 & 0.2 & 0.4 & 0.4 & 0.4 & 0.4 \\
\hline I (mA) & 5.0 & 5.0 & 2.0 & 3.0 & 4.0 & 4.0 & 4.0 & 3.0 & 3.0 & 2.0 & 2.0 \\
\hline
\end{tabular}

NB: $\lambda$ - wavelength, I - operating lamp current

\section{Results and Discussion}

\subsection{Method Validation Parameters}

The results of correlation coefficients are given in Table 4. According to (Mitra, 2003), the minimum correlation coefficient $\left(\mathrm{r}^{2}\right)$ should be 0.995 . Thus, all calibration curves in this study showed good correlation between concentration and absorbance. The method detection limits determined for leaf and root bark samples were low enough to detect the presence of interested metals at trace levels (Table 4). The reproducibility of the analytical procedure was checked by carrying out triplicate analysis and calculating the relative standard deviation (RSD) for each metal. The recommended value of RSD is less than $10 \%$ (Mitra, 2003). In this study, RSD values were below $8 \%$ (Table 4 ) of the mean which revealed that the analytical method used was precise and reliable. As shown in Table 4, the percentage recovery varied from 83.3 to $112.9 \%$, which are in the acceptable range according to Clesceri et al. (1999).

Table 4: Correlation coefficient $\left(\mathrm{r}^{2}\right)$, Method detection limit (MDL) and recovery (R) results

\begin{tabular}{|l|l|l|l|l|l|l|l|l|l|l|l|}
\hline & $\mathbf{N a}$ & $\mathbf{K}$ & $\mathbf{M g}$ & $\mathbf{C a}$ & $\mathbf{F e}$ & $\mathbf{C o}$ & $\mathbf{N i}$ & $\mathbf{C u}$ & $\mathbf{Z n}$ & $\mathbf{C d}$ & $\mathbf{P b}$ \\
\hline $\mathbf{r}^{\mathbf{2}}$ & 1.000 & 0.999 & 0.998 & 0.999 & 0.999 & 0.999 & 0.999 & 0.999 & 0.999 & 0.999 & 0.995 \\
\hline $\mathbf{R}(\%)$ & 104.2 & 83.3 & 106.7 & 112.9 & 88.5 & 91.7 & 86.4 & 105.2 & 85.4 & 88.8 & 95.0 \\
\hline MDL & - & - & - & - & 0.09 & 0.03 & 0.03 & 0.002 & 0.005 & 0.01 & 0.08 \\
\hline
\end{tabular}

NB: MDL in ppm, “_"denotes not analyzed

\subsection{Concentration Level of Selected Metals in Leaf and Root bark of Malva parviflora}

This study revealed that the leaf part contains high amounts of $\mathrm{Na}, \mathrm{K}, \mathrm{Mg}$, and $\mathrm{Ca}$. Similarly, high amounts of $\mathrm{Mg}$ and $\mathrm{Ca}$ were detected in the root bark. Appreciable amounts of $\mathrm{Fe}$ and $\mathrm{Zn}$, and low amount of $\mathrm{Cu}$ were detected in both leaf part and root bark. Amounts of $\mathrm{Co}, \mathrm{Ni}, \mathrm{Cd}$, and $\mathrm{Pb}$ were below the method detection limit (Table 5).

Table 5: Average concentration (ppm) \pm SD of selected metals in leaf and root bark samples

\begin{tabular}{|c|c|c|c|c|c|c|c|c|c|c|c|}
\hline Metal & $\mathrm{Na}$ & K & Mg & $\mathrm{Ca}$ & $\mathrm{Fe}$ & $\mathrm{Cu}$ & $\mathrm{Zn}$ & $\mathbf{N i}$ & Cd & $\mathrm{Pb}$ & Co \\
\hline 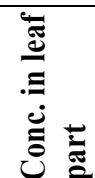 & $\begin{array}{l}1,875.0 \pm \\
97.5\end{array}$ & $\begin{array}{l}38,125.0 \\
\pm 3,011.9\end{array}$ & $\begin{array}{l}3,985.9 \\
\pm 167.4\end{array}$ & $\begin{array}{l}25,096.2 \\
\pm 777.9\end{array}$ & $\begin{array}{l}296.2 \\
\pm 4.6\end{array}$ & $\begin{array}{l}3.40 \\
\pm 0.02\end{array}$ & $\begin{array}{l}59.1 \\
\pm 0.9\end{array}$ & ND & ND & ND & $\mathrm{NA}$ \\
\hline 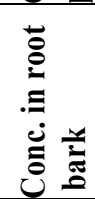 & $\mathrm{NA}$ & NA & $\begin{array}{l}3,614.4 \\
\pm 133.7\end{array}$ & $\begin{array}{l}13,427.1 \\
\pm 590.8\end{array}$ & $\begin{array}{l}891.2 \\
\pm 14.3\end{array}$ & $\begin{array}{l}5.45 \\
\pm 0.04\end{array}$ & $\begin{array}{l}197.5 \\
\pm 2.8\end{array}$ & ND & ND & ND & ND \\
\hline
\end{tabular}

NB: Conc. $=$ concentration, $\mathrm{ND}=$ not detected, $\mathrm{NA}=$ not analyzed

The concentration level $(38125.0 \pm 3011.9 \mathrm{ppm})$ of $\mathrm{K}$ indicates that leaf part of Malva parviflora rich in this element. $\mathrm{K}$ is the most abundant cation in the human body and its presence in edible part at high level is important (Ashraf et al., 2010). A daily recommended amount of $\mathrm{K}$ for adult is $4,700 \mathrm{mg} /$ day (Ismail et al., 2011). $\mathrm{K}$ is a major component of many soils and derived from the weathering of soil parent materials such as potassiumaluminium-silicates. Other factors that increase amount of $\mathrm{K}$ in soils are application of fertilizers (Kirmani et al., 2011) and plants and other organisms holding $\mathrm{K}$ as free ions in their cells, once they die; it quickly reenters the 
soil solution (Grouh and Boroomand, 2012). The high amount of $\mathrm{K}$ in the leaf part may be attributed to the preferential uptake of $\mathrm{K}$ from the soil by Malva parviflora. This is further weak attachment of $\mathrm{K}$ to the soil particles which leads way for high leachability and absorption by plant roots (Grouh and Boroomand, 2012).

The concentration of $\mathrm{Na}$ detected in leaf sample was $1,875.0 \pm 97.5 \mathrm{ppm}$. The $\mathrm{Na}$ daily recommended range in developing countries is between $2400-5175 \mathrm{mg} /$ day (Ismail et al., 2011). The common salt which is used in cooking foods is the major source of Na uptake (Kirmani et al., 2011). Therefore, Malva parviflora leaf is important alternative source of $\mathrm{Na}$ for patients who could not use table salt.

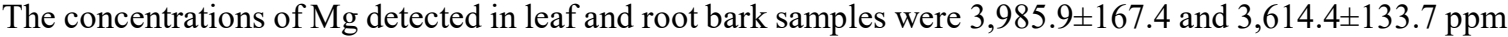
respectively. This result indicates Malva parviflora is a good source of $\mathrm{Mg}$. The high content of $\mathrm{Mg}$ in this plant may be due to high absorption of $\mathrm{Mg}$ from the soil by the plant. $\mathrm{Mg}$ is widely distributed in animal foods and plants (Mohammed and Sharif, 2011). The overuse of fertilizers can accumulate high amount of $\mathrm{Mg}$ in top soils (Papastergios et al., 2004). The daily recommended amount of $\mathrm{Mg}$ is 320-420 gm/day (Mohammed and Sharif, 2011). It plays an important role in protein synthesis (Ismail et al., 2011), and its deficiency could be prevented by adequate consumption of leaf of Malva parviflora. The presence of $\mathrm{Mg}$ in medicinal plants enhances their antibacterial activity of against Staphylococcus aureus and Escherichia coli (Pandey and Karanwal, 2011) and actively promoting wound healing (Martiniakova et al., 2009). Thus, its presence in Malva parviflora root bark might contributes wound healing and antibacterial activity of the plant.

The high amounts $(25,096.2 \pm 777.9$ and $13,427.1 \pm 590.8 \mathrm{ppm})$ of Ca were detected in Malva parviflora leaf and root bark respectively. In plants, leaf parts relatively contain high of $\mathrm{Ca}$ (Perveen et al., 2012). It is one of the most abundant mineral in the human body (Selvaraju et al., 2011), and the necessary daily intake is between 350 and $1,100 \mathrm{mg}$ /day (Stef et al., 2010). The high Ca content in the leaf of Malva parviflora suggests its possible use to overcome $\mathrm{Ca}$ deficiency. Ca also contributes antibacterial activity of medicinal plants against Staphylococcus aureus and Escherichia coli (Pandey and Karanwal, 2011) and promotes wound healing (Martiniakova et al., 2009).

The concentration levels of $\mathrm{Fe}$ in leaf and root bark samples were $296.2 \pm 4.6$ and $891.2 \pm 14.3 \mathrm{ppm}$ respectively. The amount of Fe in leaf part was below the maximum permitted level $(425 \mathrm{ppm})$ in vegetables (Uwah et al., 2012). In this study, Fe was found high in leaf part, which is probably due to Fe-rich soil of the study area. Fe deficiency is one of the most prevalent nutritional deficiencies in the world (Ondo et al., 2012). Therefore, use of Malva parviflora leaf in food preparation may be advised. The concentration of $\mathrm{Fe}$ in the root bark was in agreement with the amounts of Fe in selective medicinal herbs of Egypt (Maobe et al., 2012). It is a key to wound healing wound healing (Martiniakova et al., 2009) and enhances antibacterial activity of medicinal plants against Staphylococcus aureus and Escherichia coli (Pandey and Karanwal, 2011). Thus, the presence of Fe in root bark of Malva parviflora might contribute to its medicinal value.

The concentrations of $\mathrm{Zn}$ in leaf and root bark samples were $59.1 \pm 0.9$ and $197.5 \pm 2.8 \mathrm{ppm}$ respectively. According to Ismail et al. (2011), the concentration of $\mathrm{Zn}$ in leaf of Malva parviflora was below the maximum limit of $\mathrm{Zn}$ in vegetables (100 ppm). Besides, the range of $\mathrm{Zn}$ in agricultural products should be between 15 to 200 ppm (Jabeen et al., 2010). About $20 \%$ of the world's population could be at risk of Zn deficiency (Bhowmik et al., 2012). The present study revealed that Malva parviflora leaf is a good source of $\mathrm{Zn}$, and it can be advantage to overcome the Zn deficiency. It has also antibacterial activity against Staphylococcus aureus and Escherichia coli (Pandey and Karanwal, 2011) and plays a vital role in wound healing (Martiniakova et al., 2009).

The amounts of $\mathrm{Cu}$ in leaf and root bark samples were $3.40 \pm 0.02$ and $5.45 \pm 0.04$ ppm respectively. Its maximum limit in vegetables is $73 \mathrm{ppm}$ (Shagal et al., 2012). Permissible limits in medicinal plants for $\mathrm{Cu}$ set by China and Singapore were $20 \mathrm{ppm}$ and $150 \mathrm{ppm}$ respectively (Maobe et al., 2012). The concentrations of Cu in both leaf and root bark of Malva parviflora were below limits. Most plants contain inadequate amount of $\mathrm{Cu}$ for their normal growth due its low mobility within plant tissues and uptake relative to other (Ondo et al., 2012). Cu has also antibacterial activity against Escherichia coli (Varkey, 2010), and it promotes wound healing (Burns et al., 2003).

Concentrations of $\mathrm{Cd}, \mathrm{Ni}, \mathrm{Pb}$, and $\mathrm{Co}$ were not detected in this study. The failure to detection might due to their amounts were below the detection limits of the techniques used. Since Ni is essential micronutrient, its adequate supply for growing vegetables should be ensured through artificial or organic fertilizers (Itanna, 2002).

\section{Conclusion}

The present study revealed that leaf part of Malva parviflora contains high amounts of $\mathrm{Na}, \mathrm{K}, \mathrm{Mg}$, and $\mathrm{Ca}$. Similarly, high concentrations of $\mathrm{Mg}$ and $\mathrm{Ca}$ were detected in the root bark. Appreciable amounts of $\mathrm{Fe}$ and $\mathrm{Zn}$, and low amount of $\mathrm{Cu}$ were detected in both leaf part and root bark. Concentrations of $\mathrm{Co}, \mathrm{Ni}, \mathrm{Cd}$, and $\mathrm{Pb}$ were below the method detection limit. Since metals such as $\mathrm{Na}, \mathrm{K}, \mathrm{Mg}, \mathrm{Ca}, \mathrm{Fe}, \mathrm{Cu}$, and $\mathrm{Zn}$ play an important role to maintain a good human health, it's confirmed that the leaf of Malva parviflora is used for nutritional purposes. Besides, the results revealed that the leaf of Malva parviflora is a good source of these essential nutrients. The presence of high amount of $\mathrm{Mg}, \mathrm{Ca}, \mathrm{Fe}, \mathrm{Zn}$ and $\mathrm{Cu}$ in the root bark might contribute to the therapeutic action of 
Malva parviflora.

\section{References}

Ashraf, M., Hayat, M.Q., Mumtaz, A.S. (2010). A Study on elemental contents of medicinally important species of Artemisia L (Asteraceae) found in Pakistan. J Med Plant Res 4(21):2256-2263.

Bhowmik ,S., Datta, B.K., Saha, A.K. (2012). Determination of mineral content and heavy metal content of some traditionally important aquatic plants of Tripura, India using atomic absorption spectroscopy. Journal of Agricultural Technology 8(4):1467-1476.

Burns, J., Phillips, L.G., Mancoll, J.S. (2003). Impairments to wound healing. Clin Plast Surg 30:47-56.

Chakraborty, S.P., Pramanik, P., Roy, S. (2012). A review on-emergence of antibiotic resistant Staphylococcus aureus and role of Chitosan nanoparticle in drug delivery. Int J Life Sci Pharma Res 2(1):96-115.

Clesceri, L.S., Greenberg, A.E., Eaton, A.D. (eds) (1999). Standard methods for the examination of water and wastewater, $20^{\text {th }}$ edn. American Public Health Association, American Water Works Association, Water Environment Federation, USA.

Gentscheva, G.D., Stafilov, T., Ivanova, E.H. (2010). Determination of some essential and toxic elements in herbs from Bulgaria and Macedonia using atomic spectrometry. Eurasian Anal Chem 5(2):104-111.

Grouh, S.H.M., Boroomand, N. (2012). Macroelements nutrition (NPK) of medicinal plants: A review. J Med Plants Res 6(12): 2249-2255.

Hussain, J., Rehman N.U., Khan, A.L., Hamayun, M., Hussain, S.M., Shinwari, Z.K. (2010). Proximate and essential nutrients evaluation of selected vegetables species from Kohat Region, Pakistan..Pak J Bot 42(4):2847-2855.

Ismail, F., Anjum, M.R., Mamon, A.N., Kazi, T.G. (2011). Trace metal contents of vegetables and fruits of Hyderabad Retail market. Pak J Nutr 10(4):365-372.

Itanna, F. (2002). Metals in leafy vegetables grown in Addis Ababa and toxicological implications..Ethiop J Health Dev 16(3):295-302.

Jabeen, S., Shah, M.T., Khan, S., Hayat, M.Q. (2010). Determination of major and trace elements in ten important folk therapeutic plants of Haripur basin, Pakistan. J Med Plant Res 4(7):559-566.

Kirmani, M.Z., Mohiuddin, S., Naz F., Naqvi, I.I., Zahir, E. (2011). Determination of some toxic and essential trace metals in some medicinal and edible plants of Karachi City. J basic appl sci 7(2):89-95.

Maobe, M.A.G., Gatebe, E., Gitu, L., Rotich, H. (2012). Profile of heavy metals in selected medicinal plants used for the treatment of diabetes, malaria and pneumonia in Kisii Region, Southwest Kenya. Global J Pharmacol $6(3): 245-251$.

Martiniakova, M., Omelka, R., Grosskopf, B., Chovancova, H., Massanyi, P., Chrenek, P. (2009). Effects of dietary supplementation of nickel and nickel-zinc on femoral bone structure in rabbits. Acta Vet Scand 51:52.

Mitra, S. (2003). Sample preparation techniques in analytical chemistry. New Jersey: John Wiley \& Sons, pp. 227264.

Mohammed, M.I., Sharif, N. (2011). Mineral composition of some leafy vegetables consumed in Kano, Nigeria. Niger J Basic Appl Sci 19(2):208-212.

Mos, I., Micle, O., Zdranca, M., Muresan, M., Vicas, L. (2010). Antibiotic sensitivity of the Escherichia coli strains isolated from infected skin wounds. Farmacia 58(5):637-645.

Ododo, M.M., Choudhury, M.K., Dekebo, A.H. (2016). Structure elucidation of $\beta$-sitosterol with antibacterial activity from the root bark of Malva parviflora. SpringerPlus 5:1210. DOI 10.1186/s40064-016-2894-x

Ondo, J.A., Prudent, P., Biyogo, R.M., Rabier, J., Eba, F., Domeizel, M. (2012). Translocation of metals in two leafy vegetables grown in urban gardens of Ntoum, Gabon. Afr J Agric Res 7(42):5621-5627.

Pandey, A., Karanwal, V. (2011). A study of extract optimization and effect of metal ions on antibacterial properties of Argemone mexicana. Asian J Plant Sci Res 1(2):43-48.

Papastergios, G., Georgakopoulos, A., Fernandez-Turiel, J.L., Gimeno, D., Filippidis A., Kassoli-Fournaraki, A., Grigoriadou, A. (2004). Heavy metals and toxic trace elements contents in soils of selected areas of the Kavala Prefecture, Northern Greece. Bulletin of the Geological Society of Greece XXXVI:263-272.

Perveen, K., Bokhari, N.A., Siddique, I., Siddiqui, I., Soliman, D.A.W. (2012). Mineral analysis of Phoenix dactylifera L. leaves by inductively coupled plasma optical emission spectroscopy. Afr J Pharm Pharmacol 6(39):2782-2786.

Selvaraju, R., Thiruppathi, G., Raman, R.G., Dhakshanamoorthy, D. (2011). Estimation of essential and trace elements in the medicinal plant Tribulus terrestris by ICP-OES and flame photometric techniques. ROM J BIOL-PLANT BIOL 56(1):65-75.

Shagal, M.L., Maina, H.M., Donatu, R.B., Tadzabia, K. (2012). Bioaccumulation of trace metals concentration in some vegetables grown near refuse and effluent dumpsites along Rumude Doubeli bye-pass in Yola North, Adamawa State. Glo Adv Res J Environ Sci Toxicol 1(2):018-022.

Sharma, S.K., Ali, M. (1999). A new stigmastane derivative isolated from root of Malva parviflora. Indian J Chem 
38B:746-748.

Stef, D.S., Gergen, I., Stef, L., Harmanescu, M., Pop, C., Druga, M., Bujanca, G., Popa, M. (2010). Determination of the macro elements content of some medicinal herbs. Scientific Papers:Animal Science and Biotechnologies 43(1):122-126.

Uwah, E.I., Gimba, M.S.B., Gwaski, P.A. (2012). Determination of $\mathrm{Zn}, \mathrm{Mn}, \mathrm{Fe}$ and $\mathrm{Cu}$ in spinach and lettuce cultivated in Potiskum, Yobe State, Nigeria. J Agric Econ Dev 1(4):69-74.

Varkey, A.J. (2010). Antibacterial properties of some metals and alloys in combating coliforms in contaminated water. Sci Res Essays 5(24):3834-3839. 